\title{
Transcriptional Regulation in Prostate Cancer
}

\author{
David P. Labbé ${ }^{1,2}$ and Myles Brown ${ }^{1}$ \\ ${ }^{1}$ Department of Medical Oncology, Dana-Farber Cancer Institute, Harvard Medical School and Center for \\ Functional Cancer Epigenetics, Dana-Farber Cancer Institute, Boston, Massachusetts 02215 \\ Correspondence: myles_brown@dfci.harvard.edu
}

Prostate cancer development involves corruption of the normal prostate transcriptional network, following deregulated expression or mutation of key transcription factors. Here, we provide an overview of the transcription factors that are important in normal prostate homeostasis (NKX3-1, p63, androgen receptor [AR]), primary prostate cancer (ETS family members, c-MYC), castration-resistant prostate cancer (AR, FOXA1), and AR-independent castration-resistant neuroendocrine prostate cancer (RB1, p53, N-MYC). We use functional (in vitro and in vivo) as well as clinical data to discuss evidence that unveils their roles in the initiation and progression of prostate cancer, with an emphasis on results of chromatin immunoprecipitation followed by high-throughput sequencing (ChIP-seq).

$\mathrm{C}$ ell-specific gene expression programs are governed by a combination of transcription factors and cofactors that control enhancer function (Arnone and Davidson 1997). In any given cell type, a distinct set of enhancers remain active, to preserve cellular identity. However, enhancer accessibility is a dynamic feature, because epigenetic modifications such as histone methylation/acetylation and DNA methylation can alter regions of euchromatin (i.e., lightly packed chromatin) as well as heterochromatin (i.e., tightly packed chromatin) and thus rewire the sets of active enhancers within a cell. This fundamental aspect of cell transcriptional plasticity driven by epigenetic modifications is involved in both normal prostate and cancer settings and has been thoroughly reviewed by Yegnasubramanian (2018). Here, we focus on the transcription factors that are critical for maintaining normal prostatic tissues and tissues that are deregulated in primary prostate cancer; we also review the major transcription factors implicated in the transcriptional rewiring that follows androgen-deprivation therapy and the factors involved in the emergence and maintenance of castration-resistant prostate cancer (CRPC) plus castration-resistant neuroendocrine prostate cancer (CRPC-NE) (Fig. 1). We pay particular attention to conclusions derived from experiments that use chromatin immunoprecipitation of transcription factors followed by high-throughput sequencing (ChIP-seq), which address the binding of transcription factors to DNA cis-regulatory elements compiled by the cistrome.org data browser (Mei et al. 2017).

\footnotetext{
${ }^{2}$ Present address: Division of Urology, Department of Surgery, McGill University and Research Institute of the McGill University Health Centre, Montréal, Québec H4A 3J1, Canada

Editors: Michael M. Shen and Mark A. Rubin

Additional Perspectives on Prostate Cancer available at www.perspectivesinmedicine.org

Copyright (C) 2018 Cold Spring Harbor Laboratory Press; all rights reserved; doi: 10.1101/cshperspect.a030437

Cite this article as Cold Spring Harb Perspect Med 2018;8:a030437
} 
D.P. Labbé and M. Brown

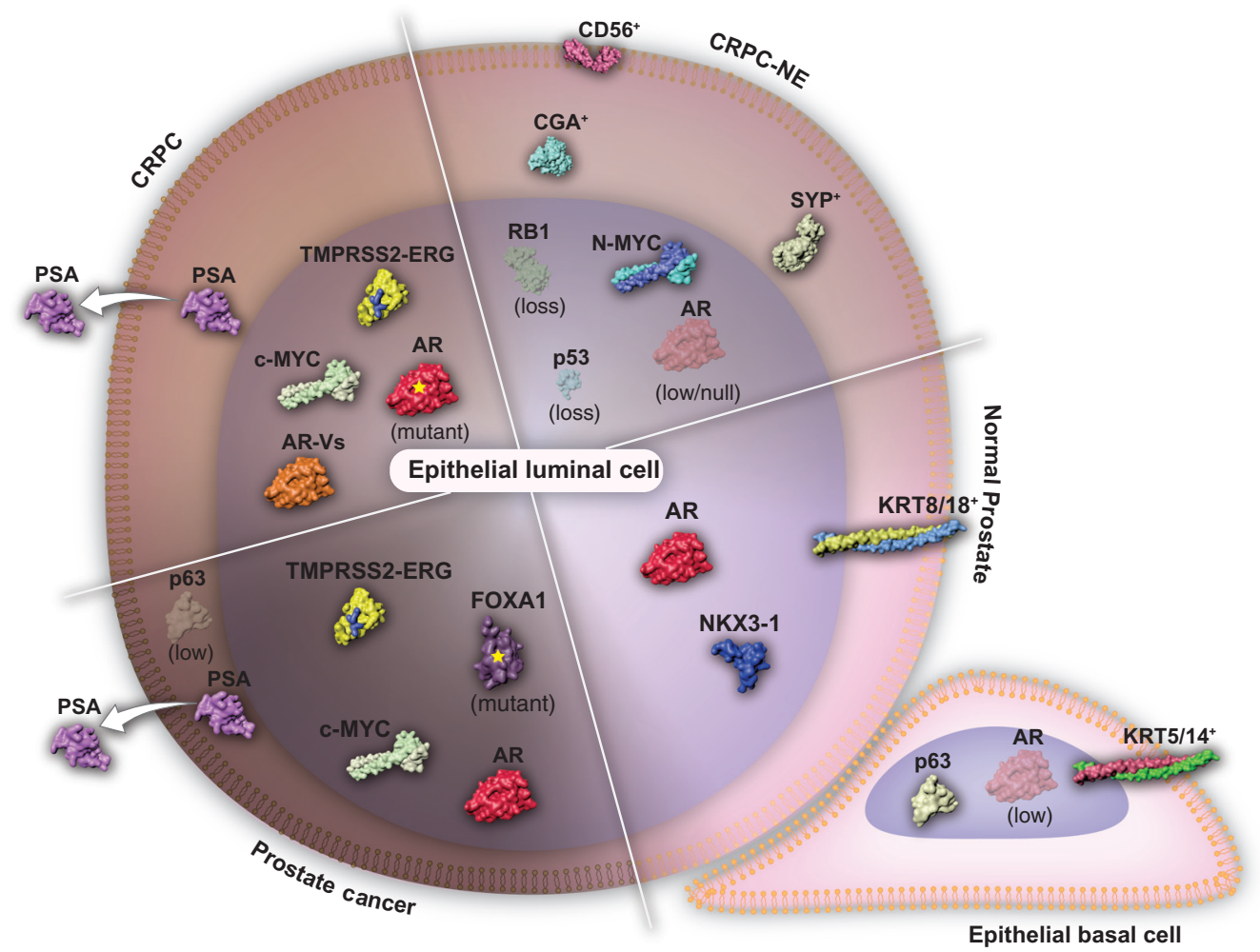

Figure 1. Evolution of the prostate cancer network of transcription factors throughout disease progression. Normal prostate epithelium consists of basal $\left(\mathrm{KRT} 5 / 14^{+}\right)$and luminal cells (KRT8/18 ${ }^{+}$) with a transcriptional network governed by p63 or AR and NKX3-1, respectively. Prostate cancer is characterized by the expansion of AR-dependent epithelial cells harboring genetic alterations such as TMPRSS2-ERG gene fusion, $c-M Y C$ amplification, and FOXA1 mutations. The loss of the epithelial basal cell layer and the disruption of the normal tissue architecture results in the secretion of trackable levels prostate-specific antigen (PSA) into the bloodstream. The first line of androgen receptor (AR)-directed therapy results in the emergence of a castration-resistant prostate cancer (CRPC) through AR amplification, mutation, or the formation of AR messenger RNA (mRNA) splice variants (AR-Vs). Castration-resistant neuroendocrine prostate cancer (CRPC-NE) emerges following the resistance to the second generation of AR-targeted therapies. In contrast to the other stages of the disease, CRPC-NE $\left(\mathrm{SYP}^{+} / \mathrm{CGA}^{+} / \mathrm{CD} 56^{+}\right)$is $\mathrm{AR}$ independent and is often driven by MYCN amplification (encoding $\mathrm{N}-\mathrm{MYC}$ ) and the loss of RB1 and TP53 (encoding p53) tumor-suppressing genes.

\section{TRANSCRIPTIONAL MAINTENANCE OF NORMAL PROSTATE IDENTITY}

\section{NKX3-1}

The NKX3-1 homeobox gene is one of the earliest genes expressed during the prostatic epithelium maturation (Bhatia-Gaur et al. 1999), and is known to play a critical role in maintaining tissue identity. Forced expression of $N k \times 3-1$ in fully differentiated murine seminal vesicle epithelium is sufficient to reprogram cells to a prostatic epithelium (Dutta et al. 2016). In adult prostate, $N k x 3-1$ is expressed in all luminal cells (that express keratin $8 / 18$; KRT8/18) as well as in a subset $(\sim 10 \%)$ of basal cells (that express keratin 5/14; KRT5/14) (Wang et al. 2009b); this expression is critical for the differentiation of the prostate epithelium. Indeed, germline loss of function (Bhatia-Gaur et al. 1999) or conditional deletion (Abdulkadir et al. 2002) of Nkx3-1 in the prostate leads to dysplasia. With increasing age, dysplasia is followed by prostatic intraepithelial neoplasia (PIN). Importantly, although compromised Nkx3-1 expression in murine 
prostate leads to PIN, which often precedes the onset of invasive adenocarcinoma in humans (Bostwick et al. 2004), it is not sufficient to trigger disease progression. Those observations are in line with the finding that loss of $N K X 3-1$ is a frequent and early event in human prostate cancer etiology. Using their model of punctuated evolution of prostate cancer genomes, Baca and coworkers concluded that loss of NKX3-1 is a clonal event that precedes the loss of other progression-associated lesions, such as loss of CDKN1B, TP53, or PTEN (Baca et al. 2013). Also, germline sequence variants of NKX3-1, which decrease NKX3-1's DNA binding, are associated with hereditary prostate cancer (Zheng et al. 2006). Genome-wide association studies (GWAS) revealed a functional NKX3-1 variant associated with sporadic prostate cancer, caused by reduced NKX3-1 gene expression (Eeles et al. 2009; Akamatsu et al. 2010; Takata et al. 2010). Thus, loss of NKX3-1 is a tumor-initiating event that disrupts normal prostate epithelial differentiation and sets the stage for a chain of oncogenic events.

Interestingly, NKX3-1 is intertwined in a network of transcription factors that define prostate cell fate. NKX3-1 and the androgen receptor $(A R)$ directly regulate each other in a feedforward loop (Tan et al. 2012), while NKX31 and MYC cross-regulate shared target genes in prostate tumorigenesis (Anderson et al. 2012). In addition, $M Y C$ and $A R$ are the most frequently amplified genes in primary and metastatic prostate cancer, respectively (Cancer Genome Atlas Research Network 2015), which suggests that loss of NKX3-1 is a tumor-initiating event that irreversibly alters prostate transcriptional regulation.

p63

p63 (encoded by TP63) is a member of the p53 family of transcription factors and is a prostate basal cell marker (Signoretti et al. 2000). TP63 encodes two amino-terminal (TA and $\Delta \mathrm{N}$ ) and three carboxy-terminal $(\alpha, \beta$, and $\gamma)$ variants, for a combination of six different p63 protein products (Yang et al. 1998); the $\Delta \mathrm{N}$ isoform is expressed at high levels in the nucleus of prostate basal cells (Signoretti et al. 2000). Tp63-null mice die at birth and show severe developmental defects such limb truncations, craniofacial malformations, and lack of an intact epidermis (Mills et al. 1999; Yang et al. 1999). Notably, they fail to develop the prostate (Signoretti et al. 2000), a phenotype that is largely recapitulated by the specific deletion of the $\Delta \mathrm{Np} 63$, but not the TAp63 isoform (Suh et al. 2006; Romano et al. 2012); this phenotype leads to the hypothesis that $\Delta \mathrm{Np} 63$-expressing cells are in fact prostatic stem cells, which are required for the generation of $\Delta \mathrm{Np63-negative} \mathrm{prostate} \mathrm{luminal} \mathrm{cells.} \mathrm{Results}$ of genetic lineage tracing validate this hypothesis (Pignon et al. 2013).

Because prostate adenocarcinoma lacks basal cells, immunostaining for p63 can be used in the clinic to distinguish - with high sensitivity and specificity-prostate cancer from benign mimics (Shah et al. 2002). Although low-cytoplasmic immunoreactivity for p63 is observed in a rare subset of tumor cells, an aberrant expression is associated with increased prostate cancer-specific mortality (Dhillon et al. 2009). This result may be attributed the finding that p63-expressing tumors represent a molecularly distinct subclass, which is characterized by preserved expression of typical prostate luminal-type proteins such as NKX3-1 and AR, yet which maintains a basal-like phenotype (Tan et al. 2015). Given the critical role of $\mathrm{p} 63$ for prostate epithelial development and homeostasis, as well as for prostate cancer diagnosis and prognosis, it is surprising that, to date, only a single prostatecentric study has interrogated the p63 cistrome (Olsen et al. 2013), leaving untapped a wealth of exciting questions.

\section{AR}

$\mathrm{AR}$, a ligand-inducible transcription factor, plays a critical role in the maintenance of normal prostate epithelium homeostasis. In 1893, surgical castration performed on 11 dogs was shown to result in a rapid atrophy of the gland, caused by an overall reduction in the bulk and weight of the prostates compared with those in noncastrated animals (White 1893). Two years later, in a trial aimed at improving the condition of 
men suffering from a hypertrophy of the prostate, White (1895) reported 102 cases with surgical castration, $87 \%$ of which displayed clear evidence of reduced prostate size. Now, more than 100 years later, it is clear that in normal prostatic tissues, androgen deprivation triggers apoptosis in the epithelial compartment and leads to gland involution, a phenotype that results from an intricate cross talk between the stromal and epithelial compartments. Tissue recombinant experiments reveal that stromal AR, which is expressed at high levels in the prostate, maintains the integrity of murine prostatic epithelial tissues by binding to androgen; thus, androgen withdrawal disrupts the homeostasis between the stromal and epithelial compartments and results in apoptosis of epithelial cells, an effect that is mediated via altered paracrine signaling by stromal cells (Kurita et al. 2001). Recent mapping of the stromal AR cistrome in human primary embryonic prostate fibroblasts, prostatic stromal cells, and even cancer-associated fibroblasts revealed that the proportion of AR binding to androgen-response element (ARE) sequence is marginal in stromal cells compared with that observed in epithelial cells $(0.30 \%$ $3.4 \%$ vs. $7.1 \%-31.4 \%$ ), strengthening the evidence of a distinct AR transcriptional network in prostate stromal cells (Nash et al. 2017).

On the other hand, epithelial AR is also central to the mature prostate gland. Indeed, epithelial-specific deletion of AR points to a role for $\mathrm{AR}$ in maintaining epithelial differentiation and suppressing cell proliferation in normal prostate gland (Wu et al. 2007). In AR wild-type animals, castration severely compromises the loading of AR onto chromatin, and this effect is rescued by short-term treatment with testosterone, which then leads to the restoration of an AR-dependent transcriptional program over time (Pihlajamaa et al. 2014). When integrating transcriptomic with ChIP-seq data, Pomerantz et al. (2015) showed that differentially expressed genes enriched in normal prostates (in comparison with the prostate cancer transcriptome) were also significantly associated with a subset of AR-binding sites unique to the normal prostatic tissue. Therefore, activation of AR by androgens sustains a transcriptional program that is necessary for the maintenance of normal prostate epithelium homeostasis. This AR dependency of prostatic tissues reveals an intrinsic vulnerability that was exploited $>70$ years ago for the treatment of prostate cancer, and to this day it remains the cornerstone of modern therapy.

\section{PROSTATE CANCER TRANSCRIPTIONAL REPROGRAMING}

\section{ETS-Mediated Transcription}

The most frequent genomic alteration in primary prostate cancer is the recurrent gene fusion of the $5^{\prime}$ untranslated region of TMPRSS2 to members of the ETS transcription factor family. The TMPRSS2-ERG gene fusion (Tomlins et al. 2005 ), observed in $46 \%$ of primary prostate cancer, is by far the most frequent chromosomal rearrangement involving ETS family members, followed by ETV1 (8\% [Tomlins et al. 2005]), ETV4 (4\% [Tomlins et al. 2006]), and FLI1 (<1\%) fusions or overexpression (Cancer Genome Atlas Research Network 2015). Importantly, the $5^{\prime}$ untranslated region of TMPRSS2 is androgenregulated, and its fusions with ETS family members result in the hijacking of ETS expression and transcriptional program by the AR. Combined with cases of ETS overexpression, this results in roughly six out of 10 primary prostate cancer cases that have a deregulated ETS transcriptional program (Cancer Genome Atlas Research Network 2015). Genetically engineered mouse models that overexpress ETV1 (FVB strain [Tomlins et al. 2007]) or ERG (129/Sv strain [Klezovitch et al. 2008] or FVB strain [Tomlins et al. 2008]) under the control of the androgen-dependent ARR2 $\mathrm{Pb}$ promoter, specifically in the prostate, reveal the emergence of PIN lesions, which represents a premalignant condition that often precedes the onset of invasive adenocarcinoma in humans (Bostwick et al. 2004). Similar studies have revealed that this phenotype may be particularly sensitive to the genetic background, because overexpression of ETV1 (Carver et al. 2009) and ERG (Chen et al. 2013 ) in the C57BL/6 strain result in no appreciable phenotype or in focal prostatic hyperplasia, respectively. These results are in line with the 
actual consensus path of prostate cancer tumor evolution, suggesting that-as with the loss of NKX3-1-ETS-related genomic events such as TMPRSS2-ERG gene fusion are a very early if not an initiating event per se (Baca et al. 2013). Importantly, ERG overexpression robustly cooperates with a mouse model of prostate cancer driven by Pten loss, in which it accelerates disease progression and leads to a significant increase in invasive, poorly differentiated carcinoma and reduced survival (Chen et al. 2013). These results clearly show that ETS-mediated deregulation of the prostate transcriptional program driven by events such as TMPRSS2-ERG gene fusion, which occurs concurrently with PTEN loss (Taylor et al. 2010), is critical to the etiology of the disease.

Experiments on genome-wide chromosome conformation capture (Hi-C), using a normal benign prostate epithelial cell line (RWPE1), show that forced ERG overexpression leads to profound alterations in chromatin interactions and suggest that ERG overexpression alone is sufficient to initiate transcriptional rewiring in normal prostatic cells (Rickman et al. 2012). One of the suggested outputs of such ERG-mediated rewiring in RWPE1 cells is the RAS/mitogen-activated protein kinases (MAPK) transcriptional program; even in the absence of MAPK activation, this feature is also phenocopied by ETV1 overexpression (Hollenhorst et al. 2011). In prostate cancer settings, experiments performed on VCaP cells show that ERG cistrome is extended by nearly sixfold compared with that in ERG-overexpressing RWPE1 cells (Yu et al. 2010), which results in the disruption and suppression of AR signaling (Yu et al. 2010; Chng et al. 2012). Chen et al. (2013) found that the combination of ERG overexpression and Pten loss in murine prostatic tissues leads to restoration of $\mathrm{AR}$ transcriptional output, a phenotype that is also observed in LNCaP cells following ETV1 overexpression. It is tempting to speculate that the discrepancy between these studies relative to the relationship between ERG and $A R$ is due to the prostate cancer models used. A major difference between these models is the PTEN status: PTEN is intact in VCaP cells, whereas the LNCaP cells and the
Pten $^{\text {flox/flox }}$ prostate cancer mouse model are PTEN-null. Given that TMPRSS2-ERG gene fusion is an early event that precedes PTEN loss (Baca et al. 2013), but also co-occurs with PTEN loss as the disease progresses (Taylor et al. 2010), both models are likely to be relevant for unraveling the impact of ETS family of transcription factors deregulation on the rewiring of the prostate cancer transcriptional program, and that both models deserve our attention. Additionally, an environmental factor-such as obesity-is associated with poorer prostate cancer prognosis among men harboring the TMPRSS2-ERG gene fusion (Pettersson et al. 2013). Taken together, these findings suggest that the impact of TMPRSS2-ERG gene fusion on the prostate transcriptional program is highly context-dependent, and an array of models with different genetic alterations in multiple contexts should be studied to fully unveil the role of this fusion on prostate cancer initiation and progression.

\section{c-MYC}

The viral oncogene v-MYC acquired from the highly conserved cellular gene c-MYC was discovered more than three decades ago, and since then MYC has been a focus of attention for the cancer research community (reviewed in Dang and Eisenman 2014). In prostate cancer, c-MYC is overexpressed at early stages of the disease and acts as a key driver of tumorigenesis and disease progression (Gurel et al. 2008). Gain of chromosome $8 \mathrm{q}$ and focal amplification of $8 \mathrm{q} 24.21$ are frequent events in primary prostate cancer that are linked to amplification of $c-M Y C$ (Cancer Genome Atlas Research Network 2015). MYC overexpression is observed in up to $37 \%$ of metastatic prostate cancer patients (Kumar et al. 2016) and associated with poor survival (Ribeiro et al. 2006). Within the context of Pten loss, $c$ $M Y C$ overexpression is one of the few single gene alterations that faithfully recapitulate the primary human disease in murine prostate (Ellwood-Yen et al. 2003; Wang et al. 2003). Thus, substantial effort has been devoted to developing therapeutic approaches for targeting MYCdriven prostate cancer (Rebello et al. 2017). 
Metabolic deregulation is central to the etiology of prostate cancer (reviewed by Zadra and Loda 2017); overexpression of c-MYC in tumors has a profound impact on cell metabolism because it induces a global metabolic reprograming that supports cancer cell survival and growth (Eilers and Eisenman 2008; Dang 2013; Hsieh et al. 2015; Stine et al. 2015). At the transcriptional level, elevation of c-MYC protein levels acts like a rheostat, amplifying the output of the ongoing cellular transcriptional program (Lin et al. 2012). Notably, c-MYC is intertwined with a wealth of genetic alterations and signaling defects that are observed in prostate cancer. For example, TMPRSS2-ERG gene fusion increases levels of c-MYC protein (Sun et al. 2008; Asangani et al. 2014), which in turn drives the loss of Nkx3-1 in murine prostatic epithelial cells (Iwata et al. 2010) and likely affects the expression of Nkx3-1 and c-MYC coregulated target genes (Anderson et al. 2012). Nkx3-1 heterozygous mice that overexpress the oncogenic $\mathrm{BRAF}^{\mathrm{V} 600 \mathrm{E}}$, an activator of MAPK signaling, increase c-MYC protein levels, a feature that is further enhanced by activation of the PI3K signaling pathway that is triggered by Pten loss (Wang et al. 2012). Nowak and coworkers (2015) used another mouse model of prostate cancer to show that progression to metastasis triggered by Pten/Trp53 deficiency is driven by deregulated expression of c-MYC protein. Along these lines, c-MYC overexpression is believed to be central to the resistance of cancer cells to antiandrogen therapy, supporting the progression to a CRPC disease state (Asangani et al. 2014). Thus, although the role of $\mathrm{c}-\mathrm{MYC}$ in prostate cancer has been intensely studied, little is known concerning its cistrome in this disease -this may be caused by c-MYC's inherent instability, which affects the robustness of chromatin immunoprecipitation experiments: The half-life of c-MYC messenger RNA (mRNA) is $\sim 30 \mathrm{~min}$, whereas the half-life of its protein is in the range of $20 \mathrm{~min}$ (Farrell and Sears 2014). Collectively, these findings on how c-MYC overexpression-alone, in combination with other genetic alterations, or with environmental factors such as diet (Kobayashi et al. 2008; Blando et al. 2011)_impacts the initiation and progres- sion of prostate cancer to a metastatic disease emphasize the need to better understand how this gene is regulated and exactly what role it plays in prostate cancer progression.

\section{TRANSCRIPTIONAL REWIRING OF CASTRATION-RESISTANT PROSTATE CANCER}

\section{AR in Prostate Cancer and the Transition to Androgen-Independent AR Signaling}

Huggins first showed in 1941 that advanced and metastatic prostate cancers maintained their reliance on androgen signaling to thrive (Huggins and Hodges 1941; Huggins et al. 1941) - and for these findings, he was awarded the Nobel Prize in Physiology or Medicine in 1966. Since his discovery, targeting AR activity has been the cornerstone of the medical therapy of prostate cancer that recurs following prostatectomy or radiotherapy. Typically, the first line of treatment combines castration through the chronic use of gonadotropin-releasing hormone agonists or antagonists (Watson et al. 2015). Although treatments such as castration have an immediate impact in terms of decreasing the tumor burden and improving the quality of life of patients, the evolutionary pressure exerted on the tumor-AR signaling axis inexorably leads to the development of a CRPC. Castration-resistant disease also continues to rely on the AR for its growth and survival. AR mutations have long been recognized as a mechanism of therapeutic resistance (Taplin et al. 1995). Perhaps the most frequent mechanism for these effects is the amplification of the AR itself (Visakorpi et al. 1995), an event that significantly decreases the threshold of androgen-mediated binding of AR to the chromatin (Urbanucci et al. 2012). Such amplification is observed in more than a half of metastatic tumors (Cancer Genome Atlas Research Network 2015). The mechanisms of progression to castration resistance involving $\mathrm{AR}$ are reviewed in detail elsewhere in the literature (Centenera et al. 2018).

On its reactivation in castration-resistant disease, AR resumes part of its transcriptional program, such as the restoration of AR-driven 
prostate-specific antigen (PSA) secretion (Watson et al. 2015), while also expanding its repertoire of transcriptional targets. This might be partly because of the distinct mechanism of $A R$ action on enhancers versus suppressor elements. Indeed, the expression of the $A R$ gene itself is fine-tuned by an intronic AR-regulated element that can act as a suppressor element at high-androgen levels or as an enhancer at low-androgen levels, that results in the partial restoration of AR activity in castration-resistant disease (Cai et al. 2011), and that likely impacts the maintenance of AR binding to specific genomic loci (Decker et al. 2012). In castrationresistant disease, AR drives the selective upregulation of genes such as $U B E 2 C$, which is related to the mitotic phase of the cell cycle, a regulation not observed in androgen-dependent cells (Wang et al. 2009a). Moreover, Stelloo et al. (2015) have described a set of nine genes (DNER, EXT2, AMOTL1, RBM33, ZBTB20, $X B P 1, P M F B P 1, H S D 17 B 14$, and KLF9) that offer a distinct AR castration-resistant signature with prognostic potential. On the other hand, AR targets such as the calcium/calmodulin-dependent kinase 2 (CAMKK2) are overexpressed and $\mathrm{AR}$ regulated in both hormone-naïve and CRPC (Frigo et al. 2011; Massie et al. 2011). Treatment with AR antagonists reprogram the AR cistrome by preferentially disrupting weaker AR-binding sites (Zhu et al. 2012). Recently, Chen et al. (2015) used a motif-resolution chromatin immunoprecipitation-exonuclease (ChIPexo) approach to show that AR binds to two different motifs, based on whether it is agonistliganded (DHT) or antagonist-liganded (bicalutamide, enzalutamide), which thus results in distinct transcriptional outcomes.

The recent development of abiraterone and enzalutamide, second-generation AR-targeted therapies, has increased the survival of patients that have castration-resistant disease (de Bono et al. 2011; Scher et al. 2012). Very recently, it has been shown that the addition of abiraterone to androgen-deprivation therapy in men with locally advanced or metastatic prostate cancer improves overall and failure-free survival (James et al. 2017). However, as is the case for the first line of treatment with androgen-deprivation therapy alone, patients eventually progress to a metastatic abiraterone- or enzalutamide-castration-resistant disease (Ryan et al. 2013; Beer et al. 2014). One potential mechanism of resistance is increased expression of AR variants lacking the ligand-binding domain (AR-Vs) (Henzler et al. 2016) that can be generated through either alternative splicing or $A R$ genomic structural rearrangements. These variants possess constitutive AR activity. In particular, the AR mRNA splice variant 7 (AR-V7) has received considerable attention, and its level in circulating tumor cells has been associated with resistance to abiraterone and enzalutamide in patients with advanced disease (Antonarakis et al. 2014). Although provocative, it is unclear from these data whether AR-V7 itself is driving progression or whether its detection is a surrogate for increased full-length AR levels. Although the AR-V7 cistrome has not been characterized as yet, Lu et al. (2015) have shown that multiple AR-Vs can bind to DNA independently of wild-type AR and can modulate a specific set of genes. Another study centered on ARv567es and AR-V7 suggests that AR-Vs bind to DNA as dimers and use canonical inverted repeat AREs (Chan et al. 2015): Interestingly these investigators provide a rationale to use bromodomain and extraterminal (BET) inhibition to repress androgen-independent cell growth driven by AR-Vs through the inhibition of AR-V's transcript/protein and the abrogation of AR-V's interaction with DNA (Chan et al. 2015). This therapeutic approach has also been shown to be effective in other models of CRPC (Asangani et al. 2014). In contrast, other investigators have found that AR-V7 functions as a heterodimer with full-length AR (Watson et al. 2010; Xu et al. 2015). It will be important to better understand the functional implications of AR-Vs as a mechanism of resistance to therapies that target the AR ligand-binding domain. Taken together, these data show that altered AR signaling is at the center of the prostate cancer transcriptional network at every stage of the disease. Therefore, a better understanding of the mechanisms that direct the AR transcriptional program-from an androgen-sensitive to a castration-resistant state-is key to the success of 
D.P. Labbé and M. Brown

therapies aimed at extending the life expectancy of prostate cancer patients.

\section{Forkhead Box A1 (FOXA1)}

Most transcription factors can only bind to regions of open, accessible chromatin. On the other hand, pioneer factors are transcription factors that bind to regions embedded in closed chromatin, induce nucleosomal rearrangement that allows other transcription factors to bind, and establish a tissue-specific gene-expression program (Iwafuchi-Doi and Zaret 2014). Distinct pioneer factors are involved in the establishment of the AR transcriptional program in different tissues: HNF4 $\alpha$ in the kidney, AP- $2 \alpha$ in the epididymis, and FOXA1 in the prostate (Pihlajamaa et al. 2014). FoxA1-null prostate tissues display highly perturbed epithelial-stromal interactions with an epithelium that is characterized by basal-like cells and no differentiated or mature luminal cells, thereby highlighting the critical role of the FOXA1 transcription factor in controlling prostate cell maturation (Gao et al. 2005). Indeed, FOXA1 expression levels directly reprogram the AR cistrome (Sahu et al. 2011; Wang et al. 2011; Jin et al. 2014; Robinson et al. 2014) and to some extent also the glucocorticoid receptor (GR) cistrome (Sahu et al. 2013). FOXA1 is critical for recruiting the AR to low-affinity half-AREs. Tilting the balance toward a higher level of FOXA1 creates many open chromatin regions and constrains AR to reservoirs of abundant half-AREs, whereas lower levels of FOXA1 allow unliganded AR to liberally bind to AREs and trigger a corrupted transcriptional program (Jin et al. 2014).

Pomerantz et al. (2015) applied AR ChIPseq in both normal and prostate cancer tissues and found a unique feature of tumor tissuesnamely, that AR-binding sites colocalize with the binding motifs of FOXA1 and with the highly lineage-specific factor HOXB13. In fact, they report that simple overexpression of both transcription factors is sufficient to reprogram the normal AR cistrome to a tumor-related AR cistrome. Because FOXA1 and HOXB13 are essential for prostate cancer survival, these findings support a role for both transcription factors in cellular transformation as well as in cancer progression (Pomerantz et al. 2015). FOXA1 mutations are also frequently detected in primary prostate cancer (Cancer Genome Atlas Research Network 2015); they repress AR signaling and increase prostate cancer growth (Grasso et al. 2012). In localized, nonindolent prostate cancer, chromothripsis (or focal genomic instability) is associated with point mutations in FOXA1 (Fraser et al. 2017). This association might, in part, explain why tumors in which FOXA1 is mutated represent a distinct molecular subtype, and why such tumors are enriched in castration-resistant (Grasso et al. 2012) and metastatic disease (Cancer Genome Atlas Research Network 2015).

\section{THE TRANSCRIPTIONAL NETWORK OF AR-INDEPENDENT CASTRATION- RESISTANT PROSTATE CANCER}

As discussed above, patients treated with the second generation of AR-targeted therapies do eventually develop an abiraterone- or enzalutamide-castration-resistant disease. Although some tumors will articulate their resistance through alterations of the AR and AR-related pathways, an important subset will become AR independent. These AR-independent tumors clearly arise from prostate adenocarcinoma, but now have either reduced AR levels or are AR negative, and present histological features of small-cell carcinoma or neuroendocrine disease (reviewed by Puca et al. 2018). The mechanisms that drive this transformation are still incompletely understood but are believed to involve lineage plasticity to some extent $(\mathrm{Ku}$ et al. 2017; Mu et al. 2017). These AR-independent CRPC-NEs are positive for synaptophysin (SYP), chromogranin (CGA), or neural cell adhesion molecule 1 (CD56) (Epstein et al. 2014) and also display genomic alterations that involve key transcription factors such as the members of the E2F family (through RB1 loss), TP53, and $\mathrm{N}$-MYC, all of which affect the transcriptional program in tumors.

Loss of the tumor suppressor $R B 1$ is a very frequent event and is observed in $70 \%-85 \%$ of cases of CRPC-NE disease (Tan et al. 2014; Beltran et al. 2016). Because one of the roles of 
$\mathrm{RB} 1$ is to sequester the E2F transcription factors and thereby control cell-cycle progression, $R B 1$ loss leads to an uncontrolled cell cycle and an E2F-mediated transcriptional program (Dyson 2016); in prostate cancer cell line models, this program collaborates with AR (Ramos-Montoya et al. 2014) or EZH2 (Xu et al. 2016). In particular, $R B 1$ loss in the murine prostate results in hyperplasia, which then slowly progresses to PIN by 600 days of age (Maddison et al. 2004; Zhou et al. 2006); such a mild phenotype for a genomic alteration that is observed in latestage diseases indicates that unleashing the tumorigenesis potential of $R B 1$ loss must require preexisting molecular alterations. In fact, when combined with TP53 loss (which occurs relatively early in the evolution of prostate cancer [Baca et al. 2013] and occurs concurrently with $R B 1$ loss in more than 50\% of CRPC-NE tumors [Beltran et al. 2016]), mice develop a rapidly progressing, highly metastatic CRPC-NE disease (Zhou et al. 2006). The transgenic adenocarcinoma of the mouse prostate (TRAMP) mouse model develops a similar phenotype following inactivation of RB1 and p53 via expression of SV40 large T-antigen (Greenberg et al. 1995; Gingrich et al. 1996). As with the loss of $R B 1$, loss of TP53 alone is not sufficient to transform prostate tissues beyond the PIN stage (Zhou et al. 2006), but does lead to an altered AR cistrome in transformed, prostate cancer cell lines (Guseva et al. 2012).

Finally, gene amplification of $M Y C N$ (which encodes N-MYC) is observed in $40 \%$ of CRPCNE tumors (Beltran et al. 2011). Overexpression of this gene is significantly enriched in CRPCNE tumors and, to a lesser extent, in CRPC (Dardenne et al. 2016). A combined loss of PTEN and prostate-specific MYCN overexpression reduces AR signaling, the upshot of which is an aggressive, invasive cancer that is similar to the CRPC-NE disease in humans (Dardenne et al. 2016). Of note, mouse models of prostate cancer that are triggered by loss of Pten combined with either $R b 1$ loss ( $\mathrm{Ku}$ et al. 2017) or MYCN overexpression (Dardenne et al. 2016), both yield a CRPC-NE disease that is characterized by an EZH2-mediated transcriptional reprograming. Indeed, the use of EZH2 inhibitors compromises the growth of N-MYC-driven xenografts (Dardenne et al. 2016) and even resensitizes androgen-independent Pten/Rb1-null, as well as Pten/Rb1/Tp53-null, murine-derived prostate cancer cell lines to enzalutamide treatment (Ku et al. 2017). Considering these reports, those novel mouse models of CRPC-NE offer an exciting opportunity to study the transcriptional reprograming that occurs when prostate cancers transition to the CRPC-NE state and to use this knowledge to test novel therapeutic approaches.

\section{CONCLUDING REMARKS}

Our knowledge of normal prostate and prostate cancer transcriptional regulation has grown enormously over the last two decades. Thanks to large-scale genomic analyses and functional experiments, we now know which transcription factors are important for maintaining prostate homeostasis and which are implicated in the initiation and progression of prostate cancer. Integration of transcriptomic data with ChIPseq experiments has also enriched our understanding of the prostatic transcriptional network, especially for a handful of transcription factors. However, in most cases, we lack critical information about the transcriptional rewiring that is implicated in the clinically relevant genetic background, disease stage, or environmental contexts. Genetically engineered mouse models are invaluable tools for addressing those issues (Le Magnen et al. 2016). Given that at least one good animal model is available for each of the transcription factors reviewed herein, particular efforts should be made to study prostate transcriptional regulation in vivo. Additionally, the recent development of new experimental approaches, such as the assay for transposase-accessible chromatin (ATACseq; [Buenrostro et al. 2013]), the improvement of ChIP-seq protocols to enable the analysis of fixed clinical tissues (Cejas et al. 2016), and the increasing use of patient-derived tumor graft (PDX) and organoid culture, as well as the availability of single-cell RNA-seq, are now enabling us to tackle new and exciting research hypotheses, which should translate into life-improving treatment options for prostate cancer patients. 
D.P. Labbé and M. Brown

\section{ACKNOWLEDGMENTS}

The authors thank Dr. Noriko Uetani (for figure design and drawing) and Dr. Sonal Jhaveri (for critical review of a draft of the manuscript). D.P.L is a Lewis Katz-Young Investigator of the Prostate Cancer Foundation and is the recipient of a Scholarship for the Next Generation of Scientists from the Cancer Research Society and of a Canadian Institute of Health Research Fellowship.

\section{REFERENCES}

${ }^{*}$ Reference is also in this collection.

Abdulkadir SA, Magee JA, Peters TJ, Kaleem Z, Naughton CK, Humphrey PA, Milbrandt J. 2002. Conditional loss of $N k \times 3.1$ in adult mice induces prostatic intraepithelial neoplasia. Mol Cell Biol 22: 1495-1503.

Akamatsu S, Takata R, Ashikawa K, Hosono N, Kamatani N, Fujioka T, Ogawa O, Kubo M, Nakamura Y, Nakagawa H. 2010. A functional variant in NKX3.1 associated with prostate cancer susceptibility down-regulates NKX3.1 expression. Hum Mol Genet 19: 4265-4272.

Anderson PD, McKissic SA, Logan M, Roh M, Franco OE, Wang J, Doubinskaia I, van der Meer R, Hayward SW, Eischen CM, et al. 2012. Nkx3.1 and Myc crossregulate shared target genes in mouse and human prostate tumorigenesis. J Clin Invest 122: 1907-1919.

Antonarakis ES, Lu C, Wang H, Luber B, Nakazawa M, Roeser JC, Chen Y, Mohammad TA, Chen Y, Fedor HL, et al. 2014. AR-V7 and resistance to enzalutamide and abiraterone in prostate cancer. $N$ Engl J Med 371: 1028-1038.

Arnone MI, Davidson EH. 1997. The hardwiring of development: Organization and function of genomic regulatory systems. Development 124: 1851-1864.

Asangani IA, Dommeti VL, Wang X, Malik R, Cieslik M, Yang R, Escara-Wilke J, Wilder-Romans K, Dhanireddy S, Engelke C, et al. 2014. Therapeutic targeting of BET bromodomain proteins in castration-resistant prostate cancer. Nature 510: 278-282.

Baca SC, Prandi D, Lawrence MS, Mosquera JM, Romanel A, Drier Y, Park K, Kitabayashi N, MacDonald TY, Ghandi M, et al. 2013. Punctuated evolution of prostate cancer genomes. Cell 153: 666-677.

Beer TM, Armstrong AJ, Rathkopf DE, Loriot Y, Sternberg CN, Higano CS, Iversen P, Bhattacharya S, Carles J, Chowdhury S, et al. 2014. Enzalutamide in metastatic prostate cancer before chemotherapy. $N$ Engl J Med 371: 424-433.

Beltran H, Rickman DS, Park K, Chae SS, Sboner A, MacDonald TY, Wang Y, Sheikh KL, Terry S, Tagawa ST, et al. 2011. Molecular characterization of neuroendocrine prostate cancer and identification of new drug targets. Cancer Discov 1: 487-495.

Beltran H, Prandi D, Mosquera JM, Benelli M, Puca L, Cyrta J, Marotz C, Giannopoulou E, Chakravarthi BV, Varambally S, et al. 2016. Divergent clonal evolution of castra- tion-resistant neuroendocrine prostate cancer. Nat Med 22: 298-305.

Bhatia-Gaur R, Donjacour AA, Sciavolino PJ, Kim M, Desai N, Young P, Norton CR, Gridley T, Cardiff RD, Cunha GR, et al. 1999. Roles for $N k x 3.1$ in prostate development and cancer. Genes Dev 13: 966-977.

Blando J, Moore T, Hursting S, Jiang G, Saha A, Beltran L, Shen J, Repass J, Strom S, DiGiovanni J. 2011. Dietary energy balance modulates prostate cancer progression in Hi-Myc mice. Cancer Prev Res (Phila) 4: 2002-2014.

Bostwick DG, Liu L, Brawer MK, Qian J. 2004. High-grade prostatic intraepithelial neoplasia. Rev Urol 6: 171-179.

Buenrostro JD, Giresi PG, Zaba LC, Chang HY, Greenleaf WJ. 2013. Transposition of native chromatin for fast and sensitive epigenomic profiling of open chromatin, DNAbinding proteins and nucleosome position. Nat Methods 10: 1213-1218.

Cai C, He HH, Chen S, Coleman I, Wang H, Fang Z, Chen S, Nelson PS, Liu XS, Brown M, et al. 2011. Androgen receptor gene expression in prostate cancer is directly suppressed by the androgen receptor through recruitment of lysine-specific demethylase 1. Cancer Cell 20: 457-471.

Cancer Genome Atlas Research Network. 2015. The molecular taxonomy of primary prostate cancer. Cell 163: 10111025.

Carver BS, Tran J, Chen Z, Carracedo-Perez A, Alimonti A, Nardella C, Gopalan A, Scardino PT, Cordon-Cardo C, Gerald W, et al. 2009. ETS rearrangements and prostate cancer initiation. Nature 457: E1; discussion E2-3.

Cejas P, Li L, O’Neill NK, Duarte M, Rao P, Bowden M, Zhou CW, Mendiola M, Burgos E, Feliu J, et al. 2016. Chromatin immunoprecipitation from fixed clinical tissues reveals tumor-specific enhancer profiles. Nat Med 22: 685-691.

* Centenera MM, Selth LA, Ehrahimie E, Butler LM, Tilley WD. 2018. New opportunities for targeting the androgen receptor in prostate cancer. Cold Spring Harb Perspect Med doi: 10.1101/cshperspect.a030478.

Chan SC, Selth LA, Li Y, Nyquist MD, Miao L, Bradner JE, Raj GV, Tilley WD, Dehm SM. 2015. Targeting chromatin binding regulation of constitutively active AR variants to overcome prostate cancer resistance to endocrinebased therapies. Nucleic Acids Res 43: 5880-5897.

Chen Y, Chi P, Rockowitz S, Iaquinta PJ, Shamu T, Shukla S, Gao D, Sirota I, Carver BS, Wongvipat J, et al. 2013. ETS factors reprogram the androgen receptor cistrome and prime prostate tumorigenesis in response to PTEN loss. Nat Med 19: 1023-1029.

Chen Z, Lan X, Thomas-Ahner JM, Wu D, Liu X, Ye Z, Wang L, Sunkel B, Grenade C, Chen J, et al. 2015. Agonist and antagonist switch DNA motifs recognized by human androgen receptor in prostate cancer. EMBO J 34: 502516.

Chng KR, Chang CW, Tan SK, Yang C, Hong SZ, Sng NY, Cheung E. 2012. A transcriptional repressor co-regulatory network governing androgen response in prostate cancers. EMBO J 31: 2810-2823.

Dang CV. 2013. MYC, metabolism, cell growth, and tumorigenesis. Cold Spring Harb Perspect Med 3: a014217. 
Dang CV, Eisenman RN, eds. 2014. MYC and the pathway to cancer. Cold Spring Harbor Laboratory Press, Cold Spring Harbor, NY.

Dardenne E, Beltran H, Benelli M, Gayvert K, Berger A, Puca L, Cyrta J, Sboner A, Noorzad Z, MacDonald T, et al. 2016. N-Myc induces an EZH2-mediated transcriptional program driving neuroendocrine prostate cancer. Cancer Cell 30: 563-577.

de Bono JS, Logothetis CJ, Molina A, Fizazi K, North S, Chu L, Chi KN, Jones RJ, Goodman OB Jr, Saad F, et al. 2011. Abiraterone and increased survival in metastatic prostate cancer. N Engl J Med 364: 1995-2005.

Decker KF, Zheng D, He Y, Bowman T, Edwards JR, Jia L. 2012. Persistent androgen receptor-mediated transcription in castration-resistant prostate cancer under androgen-deprived conditions. Nucleic Acids Res 40: 1076510779.

Dhillon PK, Barry M, Stampfer MJ, Perner S, Fiorentino M, Fornari A, Ma J, Fleet J, Kurth T, Rubin MA, et al. 2009. Aberrant cytoplasmic expression of p63 and prostate cancer mortality. Cancer Epidemiol Biomarkers Prev 18: 595-600.

Dutta A, Le Magnen C, Mitrofanova A, Ouyang X, Califano A, Abate-Shen C. 2016. Identification of an NKX3.1-G9aUTY transcriptional regulatory network that controls prostate differentiation. Science 352: 1576-1580.

Dyson NJ. 2016. RB1: A prototype tumor suppressor and an enigma. Genes Dev 30: 1492-1502.

Eeles RA, Kote-Jarai Z, Al Olama AA, Giles GG, Guy M, Severi G, Muir K, Hopper JL, Henderson BE, Haiman CA, et al. 2009. Identification of seven new prostate cancer susceptibility loci through a genome-wide association study. Nat Genet 41: 1116-1121.

Eilers M, Eisenman RN. 2008. Myc's broad reach. Genes Dev 22: 2755-2766.

Ellwood-Yen K, Graeber TG, Wongvipat J, Iruela-Arispe ML, Zhang J, Matusik R, Thomas GV, Sawyers CL. 2003. Myc-driven murine prostate cancer shares molecular features with human prostate tumors. Cancer Cell 4: 223-238.

Epstein JI, Amin MB, Beltran H, Lotan TL, Mosquera JM, Reuter VE, Robinson BD, Troncoso P, Rubin MA. 2014. Proposed morphologic classification of prostate cancer with neuroendocrine differentiation. Am J Surg Pathol 38: 756-767.

Farrell AS, Sears RC. 2014. MYC degradation. Cold Spring Harb Perspect Med 4: a014365.

Fraser M, Sabelnykova VY, Yamaguchi TN, Heisler LE, Livingstone J, Huang V, Shiah YJ, Yousif F, Lin X, Masella AP, et al. 2017. Genomic hallmarks of localized, nonindolent prostate cancer. Nature 541: 359-364.

Frigo DE, Howe MK, Wittmann BM, Brunner AM, Cushman I, Wang Q, Brown M, Means AR, McDonnell DP. 2011. CaM kinase kinase $\beta$-mediated activation of the growth regulatory kinase AMPK is required for androgen-dependent migration of prostate cancer cells. Cancer Res 71: 528-537.

Gao N, Ishii K, Mirosevich J, Kuwajima S, Oppenheimer SR, Roberts RL, Jiang M, Yu X, Shappell SB, Caprioli $\mathrm{RM}$, et al. 2005. Forkhead box A1 regulates prostate ductal morphogenesis and promotes epithelial cell maturation. Development 132: 3431-3443.
Gingrich JR, Barrios RJ, Morton RA, Boyce BF, DeMayo FJ, Finegold MJ, Angelopoulou R, Rosen JM, Greenberg NM. 1996. Metastatic prostate cancer in a transgenic mouse. Cancer Res 56: 4096-4102.

Grasso CS, Wu YM, Robinson DR, Cao X, Dhanasekaran SM, Khan AP, Quist MJ, Jing X, Lonigro RJ, Brenner JC, et al. 2012. The mutational landscape of lethal castrationresistant prostate cancer. Nature 487: 239-243.

Greenberg NM, DeMayo F, Finegold MJ, Medina D, Tilley WD, Aspinall JO, Cunha GR, Donjacour AA, Matusik RJ, Rosen JM. 1995. Prostate cancer in a transgenic mouse. Proc Natl Acad Sci 92: 3439-3443.

Gurel B, Iwata T, Koh CM, Jenkins RB, Lan F, Van Dang C, Hicks JL, Morgan J, Cornish TC, Sutcliffe S, et al. 2008. Nuclear MYC protein overexpression is an early alteration in human prostate carcinogenesis. Mod Pathol 21: 1156-1167.

Guseva NV, Rokhlin OW, Bair TB, Glover RB, Cohen MB. 2012. Inhibition of $\mathrm{p} 53$ expression modifies the specificity of chromatin binding by the androgen receptor. Oncotarget 3: 183-194.

Henzler C, Li Y, Yang R, McBride T, Ho Y, Sprenger C, Liu G, Coleman I, Lakely B, Li R, et al. 2016. Truncation and constitutive activation of the androgen receptor by diverse genomic rearrangements in prostate cancer. Nat Commun 7: 13668.

Hollenhorst PC, Ferris MW, Hull MA, Chae H, Kim S, Graves BJ. 2011. Oncogenic ETS proteins mimic activated RAS/MAPK signaling in prostate cells. Genes Dev 25: 2147-2157.

Hsieh AL, Walton ZE, Altman BJ, Stine ZE, Dang CV. 2015. MYC and metabolism on the path to cancer. Semin Cell Dev Biol 43: 11-21.

Huggins C, Hodges CV. 1941. Studies on prostatic cancer. I: The effect of castration, of estrogen and of androgen injection on serum phosphatases in metastatic carcinoma of the prostate. Cancer Res 1: 293-297.

Huggins C, Stevens RE, Hodges CV. 1941. Studies on prostate cancer. II: The effects of castration on advanced carcinoma of the prostate gland. Arch Surg 43: 209-223.

Iwafuchi-Doi M, Zaret KS. 2014. Pioneer transcription factors in cell reprogramming. Genes Dev 28: 2679-2692.

Iwata T, Schultz D, Hicks J, Hubbard GK, Mutton LN, Lotan TL, Bethel C, Lotz MT, Yegnasubramanian S, Nelson WG, et al. 2010. MYC overexpression induces prostatic intraepithelial neoplasia and loss of $\mathrm{Nkx} 3.1$ in mouse luminal epithelial cells. PLoS ONE 5: e9427.

James ND, de Bono JS, Spears MR, Clarke NW, Mason MD, Dearnaley DP, Ritchie AWS, Amos CL, Gilson C, Jones RJ, et al. 2017. Abiraterone for prostate cancer not previously treated with hormone therapy. N Engl J Med 377: 338-351.

Jin HJ, Zhao JC, Wu L, Kim J, Yu J. 2014. Cooperativity and equilibrium with FOXA1 define the androgen receptor transcriptional program. Nat Commun 5: 3972.

Klezovitch O, Risk M, Coleman I, Lucas JM, Null M, True LD, Nelson PS, Vasioukhin V. 2008. A causal role for ERG in neoplastic transformation of prostate epithelium. Proc Natl Acad Sci 105: 2105-2110.

Kobayashi N, Barnard RJ, Said J, Hong-Gonzalez J, Corman DM, Ku M, Doan NB, Gui D, Elashoff D, Cohen P, et al. 
D.P. Labbé and M. Brown

2008. Effect of low-fat diet on development of prostate cancer and Akt phosphorylation in the Hi-Myc transgenic mouse model. Cancer Res 68: 3066-3073.

Ku SY, Rosario S, Wang Y, Mu P, Seshadri M, Goodrich ZW, Goodrich MM, Labbé DP, Gomez EC, Wang J, et al. 2017. $\mathrm{Rb} 1$ and Trp53 cooperate to suppress prostate cancer lineage plasticity, metastasis, and antiandrogen resistance. Science 355: 78-83.

Kumar A, Coleman I, Morrissey C, Zhang X, True LD, Gulati R, Etzioni R, Bolouri H, Montgomery B, White T, et al. 2016. Substantial interindividual and limited intraindividual genomic diversity among tumors from men with metastatic prostate cancer. Nat Med 22: 369-378.

Kurita T, Wang YZ, Donjacour AA, Zhao C, Lydon JP, O'Malley BW, Isaacs JT, Dahiya R, Cunha GR. 2001. Paracrine regulation of apoptosis by steroid hormones in the male and female reproductive system. Cell Death Differ 8: 192-200.

Le Magnen C, Dutta A, Abate-Shen C. 2016. Optimizing mouse models for precision cancer prevention. Nat Rev Cancer 16: 187-196.

Lin CY, Loven J, Rahl PB, Paranal RM, Burge CB, Bradner JE, Lee TI, Young RA. 2012. Transcriptional amplification in tumor cells with elevated c-Myc. Cell 151: 56-67.

Lu J, Lonergan PE, Nacusi LP, Wang L, Schmidt LJ, Sun Z, Van der Steen T, Boorjian SA, Kosari F, Vasmatzis G, et al 2015. The cistrome and gene signature of androgen receptor splice variants in castration resistant prostate cancer cells. J Urol 193: 690-698.

Maddison LA, Sutherland BW, Barrios RJ, Greenberg NM 2004. Conditional deletion of $\mathrm{Rb}$ causes early stage prostate cancer. Cancer Res 64: 6018-6025.

Massie CE, Lynch A, Ramos-Montoya A, Boren J, Stark R, Fazli L, Warren A, Scott H, Madhu B, Sharma N, et al. 2011. The androgen receptor fuels prostate cancer by regulating central metabolism and biosynthesis. EMBO J 30: 2719-2733

Mei S, Qin Q, Wu Q, Sun H, Zheng R, Zang C, Zhu M, Wu J, Shi X, Taing L, et al. 2017. Cistrome Data Browser: A data portal for ChIP-Seq and chromatin accessibility data in human and mouse. Nucleic Acids Res 45: D658-D662.

Mills AA, Zheng B, Wang XJ, Vogel H, Roop DR, Bradley A. 1999. $\mathrm{p} 63$ is a 553 homologue required for limb epidermal morphogenesis. Nature 398: 708-713.

Mu P, Zhang Z, Benelli M, Karthaus WR, Hoover E, Chen CC, Wongvipat J, Ku SY, Gao D, Cao Z, et al. 2017. SOX2 promotes lineage plasticity and antiandrogen resistance in TP53- and RB1-deficient prostate cancer. Science 355: 84-88.

Nash C, Boufaied N, Mills IG, Franco OE, Hayward SW, Thomson AA. 2017. Genome-wide analysis of AR binding and comparison with transcript expression in primary human fetal prostate fibroblasts and cancer associated fibroblasts. Mol Cell Endocrinol doi: 10.1016/j. mce.2017.05.006.

Nowak DG, Cho H, Herzka T, Watrud K, DeMarco DV, Wang VM, Senturk S, Fellmann C, Ding D, Beinortas T, et al. 2015. MYC drives Pten/Trp53-deficient proliferation and metastasis due to IL6 secretion and AKT suppression via PHLPP2. Cancer Discov 5: 636-651.

Olsen JR, Oyan AM, Rostad K, Hellem MR, Liu J, Li L, Micklem DR, Haugen H, Lorens JB, Rotter V, et al.
2013. p63 attenuates epithelial to mesenchymal potential in an experimental prostate cell model. PLOS ONE 8: e62547.

Pettersson A, Lis RT, Meisner A, Flavin R, Stack EC, Fiorentino M, Finn S, Graff RE, Penney KL, Rider JR, et al. 2013. Modification of the association between obesity and lethal prostate cancer by TMPRSS2:ERG. J Natl Cancer Inst 105: 1881-1890.

Pignon JC, Grisanzio C, Geng Y, Song J, Shivdasani RA, Signoretti S. 2013. p63-Expressing cells are the stem cells of developing prostate, bladder, colorectal epithelia. Proc Natl Acad Sci 110: 8105-8110.

Pihlajamaa P, Sahu B, Lyly L, Aittomaki V, Hautaniemi S, Janne OA. 2014. Tissue-specific pioneer factors associate with androgen receptor cistromes and transcription programs. EMBO J 33: 312-326.

Pomerantz MM, Li F, Takeda DY, Lenci R, Chonkar A, Chabot M, Cejas P, Vazquez F, Cook J, Shivdasani RA, et al. 2015. The androgen receptor cistrome is extensively reprogrammed in human prostate tumorigenesis. Nat Genet 47: 1346-1351.

* Puca L, Vlachostergios PJ, Beltran H. 2018. Neuroendocrine differentiation in prostate cancer: Emerging biology, models, and therapy. Cold Spring Harb Perspect Med doi: 10.1101/cshperspect.a030593.

Ramos-Montoya A, Lamb AD, Russell R, Carroll T, Jurmeister S, Galeano-Dalmau N, Massie CE, Boren J, Bon H, Theodorou V, et al. 2014. HES6 drives a critical AR transcriptional programme to induce castration-resistant prostate cancer through activation of an E2F1-mediated cell cycle network. EMBO Mol Med 6: 651-661.

Rebello RJ, Pearson RB, Hannan RD, Furic L. 2017. Therapeutic approaches targeting MYC-driven prostate cancer. Genes (Basel) 8: 71.

Ribeiro FR, Jeronimo C, Henrique R, Fonseca D, Oliveira J, Lothe RA, Teixeira MR. 2006. 8q gain is an independent predictor of poor survival in diagnostic needle biopsies from prostate cancer suspects. Clin Cancer Res 12: 39613970.

Rickman DS, Soong TD, Moss B, Mosquera JM, Dlabal J, Terry S, MacDonald TY, Tripodi J, Bunting K, Najfeld V, et al. 2012. Oncogene-mediated alterations in chromatin conformation. Proc Natl Acad Sci 109: 9083-9088.

Robinson JL, Hickey TE, Warren AY, Vowler SL, Carroll T, Lamb AD, Papoutsoglou N, Neal DE, Tilley WD, Carroll JS. 2014. Elevated levels of FOXA1 facilitate androgen receptor chromatin binding resulting in a CRPC-like phenotype. Oncogene 33: 5666-5674.

Romano RA, Smalley K, Magraw C, Serna VA, Kurita T, Raghavan S, Sinha S. 2012. $\Delta$ Np63 knockout mice reveal its indispensable role as a master regulator of epithelial development and differentiation. Development 139: 772 782.

Ryan CJ, Smith MR, de Bono JS, Molina A, Logothetis CJ, de Souza P, Fizazi K, Mainwaring P, Piulats JM, Ng S, et al 2013. Abiraterone in metastatic prostate cancer without previous chemotherapy. N Engl J Med 368: 138-148.

Sahu B, Laakso M, Ovaska K, Mirtti T, Lundin J, Rannikko A, Sankila A, Turunen JP, Lundin M, Konsti J, et al. 2011. Dual role of FoxA1 in androgen receptor binding to chromatin, androgen signalling and prostate cancer. EMBO $J$ 30: 3962-3976. 
Sahu B, Laakso M, Pihlajamaa P, Ovaska K, Sinielnikov I, Hautaniemi S, Janne OA. 2013. FoxA1 specifies unique androgen and glucocorticoid receptor binding events in prostate cancer cells. Cancer Res 73: 1570-1580.

Scher HI, Fizazi K, Saad F, Taplin ME, Sternberg CN, Miller K, de Wit R, Mulders P, Chi KN, Shore ND, et al. 2012. Increased survival with enzalutamide in prostate cancer after chemotherapy. N Engl J Med 367: 1187-1197.

Shah RB, Zhou M, LeBlanc M, Snyder M, Rubin MA. 2002. Comparison of the basal cell-specific markers, 34ßE12 and p63, in the diagnosis of prostate cancer. Am J Surg Pathol 26: 1161-1168.

Signoretti S, Waltregny D, Dilks J, Isaac B, Lin D, Garraway L, Yang A, Montironi R, McKeon F, Loda M. 2000. p63 is a prostate basal cell marker is required for prostate development. Am J Pathol 157: 1769-1775.

Stelloo S, Nevedomskaya E, van der Poel HG, de Jong J, van Leenders GJ, Jenster G, Wessels LF, Bergman AM, Zwart W. 2015. Androgen receptor profiling predicts prostate cancer outcome. EMBO Mol Med 7: 1450-1464.

Stine ZE, Walton ZE, Altman BJ, Hsieh AL, Dang CV. 2015. MYC, metabolism, and cancer. Cancer Discov 5: 1024 1039.

Suh EK, Yang A, Kettenbach A, Bamberger C, Michaelis AH Zhu Z, Elvin JA, Bronson RT, Crum CP, McKeon F. 2006. p63 protects the female germ line during meiotic arrest. Nature 444: 624-628.

Sun C, Dobi A, Mohamed A, Li H, Thangapazham RL, Furusato B, Shaheduzzaman S, Tan SH, Vaidyanathan G, Whitman E, et al. 2008. TMPRSS2-ERG fusion, a common genomic alteration in prostate cancer activates CMYC and abrogates prostate epithelial differentiation. Oncogene 27: 5348-5353.

Takata R, Akamatsu S, Kubo M, Takahashi A, Hosono N, Kawaguchi T, Tsunoda T, Inazawa J, Kamatani N, Ogawa O, et al. 2010. Genome-wide association study identifies five new susceptibility loci for prostate cancer in the Japanese population. Nat Genet 42: 751-754.

Tan PY, Chang CW, Chng KR, Wansa KD, Sung WK, Cheung E. 2012. Integration of regulatory networks by NKX3-1 promotes androgen-dependent prostate cancer survival. Mol Cell Biol 32: 399-414.

Tan HL, Sood A, Rahimi HA, Wang W, Gupta N, Hicks J, Mosier S, Gocke CD, Epstein JI, Netto GJ, et al. 2014. Rb loss is characteristic of prostatic small cell neuroendocrine carcinoma. Clin Cancer Res 20: 890-903.

Tan HL, Haffner MC, Esopi DM, Vaghasia AM, Giannico GA, Ross HM, Ghosh S, Hicks JL, Zheng Q, Sangoi AR, et al. 2015. Prostate adenocarcinomas aberrantly expressing p63 are molecularly distinct from usual-type prostatic adenocarcinomas. Mod Pathol 28: 446-456.

Taplin ME, Bubley GJ, Shuster TD, Frantz ME, Spooner AE, Ogata GK, Keer HN, Balk SP. 1995. Mutation of the androgen-receptor gene in metastatic androgen-independent prostate cancer. N Engl J Med 332: 1393-1398.

Taylor BS, Schultz N, Hieronymus H, Gopalan A, Xiao Y, Carver BS, Arora VK, Kaushik P, Cerami E, Reva B, et al. 2010. Integrative genomic profiling of human prostate cancer. Cancer Cell 18: 11-22.

Tomlins SA, Rhodes DR, Perner S, Dhanasekaran SM Mehra R, Sun XW, Varambally S, Cao X, Tchinda J, Kuefer R, et al. 2005. Recurrent fusion of TMPRSS2 and ETS transcription factor genes in prostate cancer. Science 310: 644-648.

Tomlins SA, Mehra R, Rhodes DR, Smith LR, Roulston D, Helgeson BE, Cao X, Wei JT, Rubin MA, Shah RB, et al. 2006. TMPRSS2:ETV4 gene fusions define a third molecular subtype of prostate cancer. Cancer Res 66: 3396-3400.

Tomlins SA, Laxman B, Dhanasekaran SM, Helgeson BE, Cao X, Morris DS, Menon A, Jing X, Cao Q, Han B, et al. 2007. Distinct classes of chromosomal rearrangements create oncogenic ETS gene fusions in prostate cancer. Nature 448: 595-599.

Tomlins SA, Laxman B, Varambally S, Cao X, Yu J, Helgeson BE, Cao Q, Prensner JR, Rubin MA, Shah RB, et al. 2008. Role of the TMPRSS2-ERG gene fusion in prostate cancer. Neoplasia 10: 177-188.

Urbanucci A, Sahu B, Seppala J, Larjo A, Latonen LM, Waltering KK, Tammela TL, Vessella RL, Lahdesmaki H Janne OA, et al. 2012. Overexpression of androgen receptor enhances the binding of the receptor to the chromatin in prostate cancer. Oncogene 31: 2153-2163.

Visakorpi T, Hyytinen E, Koivisto P, Tanner M, Keinanen R, Palmberg C, Palotie A, Tammela T, Isola J, Kallioniemi OP. 1995. In vivo amplification of the androgen receptor gene and progression of human prostate cancer. $\mathrm{Nat} \mathrm{Ge}-$ net 9: 401-406.

Wang S, Gao J, Lei Q, Rozengurt N, Pritchard C, Jiao J, Thomas GV, Li G, Roy-Burman P, Nelson PS, et al. 2003. Prostate-specific deletion of the murine Pten tumor suppressor gene leads to metastatic prostate cancer. Cancer Cell 4: 209-221.

Wang Q, Li W, Zhang Y, Yuan X, Xu K, Yu J, Chen Z, Beroukhim R, Wang H, Lupien M, et al. 2009a. Androgen receptor regulates a distinct transcription program in an drogen-independent prostate cancer. Cell 138: 245-256.

Wang X, Kruithof-de Julio M, Economides KD, Walker D, Yu H, Halili MV, Hu YP, Price SM, Abate-Shen C, Shen MM. 2009b. A luminal epithelial stem cell that is a cell of origin for prostate cancer. Nature 461: 495-500.

Wang D, Garcia-Bassets I, Benner C, Li W, Su X, Zhou Y, Qiu J, Liu W, Kaikkonen MU, Ohgi KA, et al. 2011. Reprogramming transcription by distinct classes of enhancers functionally defined by eRNA. Nature 474: 390-394.

Wang J, Kobayashi T, Floc'h N, Kinkade CW, Aytes A, Dankort D, Lefebvre C, Mitrofanova A, Cardiff RD, McMahon M, et al. 2012. B-Raf activation cooperates with PTEN loss to drive c-Myc expression in advanced prostate cancer. Cancer Res 72: 4765-4776.

Watson PA, Chen YF, Balbas MD, Wongvipat J, Socci ND, Viale A, Kim K, Sawyers CL. 2010. Constitutively active androgen receptor splice variants expressed in castrationresistant prostate cancer require full-length androgen receptor. Proc Natl Acad Sci 107: 16759-16765.

Watson PA, Arora VK, Sawyers CL. 2015. Emerging mechanisms of resistance to androgen receptor inhibitors in prostate cancer. Nat Rev Cancer 15: 701-711.

White JW. 1893. II. The present position of the surgery of the hypertrophied prostate. Ann Surg 18: 152-188.

White JW. 1895. I. The results of double castration in hypertrophy of the prostate. Ann Surg 22: 1-80.

Wu CT, Altuwaijri S, Ricke WA, Huang SP, Yeh S, Zhang C, Niu Y, Tsai MY, Chang C. 2007. Increased prostate cell 
D.P. Labbé and M. Brown

proliferation and loss of cell differentiation in mice lacking prostate epithelial androgen receptor. Proc Natl Acad Sci 104: 12679-12684.

Xu D, Zhan Y, Qi Y, Cao B, Bai S, Xu W, Gambhir SS, Lee P, Sartor O, Flemington EK, et al. 2015. Androgen receptor splice variants dimerize to transactivate target genes. Cancer Res 75: 3663-3671.

Xu H, Xu K, He HH, Zang C, Chen CH, Chen Y, Qin Q, Wang S, Wang C, Hu S, et al. 2016. Integrative analysis reveals the transcriptional collaboration between EZH2 and E2F1 in the regulation of cancer-related gene expression. Mol Cancer Res 14: 163-172.

Yang A, Kaghad M, Wang Y, Gillett E, Fleming MD, Dotsch V, Andrews NC, Caput D, McKeon F. 1998. p63, a p53 homolog at 3q27-29, encodes multiple products with transactivating, death-inducing, dominant-negative activities. Mol Cell 2: 305-316.

Yang A, Schweitzer R, Sun D, Kaghad M, Walker N, Bronson RT, Tabin C, Sharpe A, Caput D, Crum C, et al. 1999. p63 is essential for regenerative proliferation in limb, craniofacial epithelial development. Nature 398: 714-718.

* Yegnasubramanian S. 2018. Epigenetics. Cold Spring Harb Perspect Med doi: 10.1101/cshperspect.a030445.
Yu J, Yu J, Mani RS, Cao Q, Brenner CJ, Cao X, Wang X, Wu L, Li J, Hu M, et al. 2010. An integrated network of androgen receptor, polycomb, and TMPRSS2-ERG gene fusions in prostate cancer progression. Cancer Cell 17: 443454.

* Zadra G, Loda M. 2017. Metabolic vulnerabilities of prostate cancer: Diagnostic and therapeutic opportunities. Cold Spring Harb Perspect Med doi: 10.1101/cshperspect. a030569.

Zheng SL, Ju JH, Chang BL, Ortner E, Sun J, Isaacs SD, Sun J, Wiley KE, Liu W, Zemedkun M, et al. 2006. Germ-line mutation of NKX3.1 cosegregates with hereditary prostate cancer and alters the homeodomain structure and function. Cancer Res 66: 69-77.

Zhou Z, Flesken-Nikitin A, Corney DC, Wang W, Goodrich DW, Roy-Burman P, Nikitin AY. 2006. Synergy of p53 and $\mathrm{Rb}$ deficiency in a conditional mouse model for metastatic prostate cancer. Cancer Res 66: 7889-7898.

Zhu Z, Shi M, Hu W, Estrella H, Engebretsen J, Nichols T, Briere D, Hosea N, Los G, Rejto PA, et al. 2012. Dosedependent effects of small-molecule antagonists on the genomic landscape of androgen receptor binding. $B M C$ Genomics 13: 355. 


\section{$\&_{\mathrm{CSH}}^{\infty} \&$ Cold Spring Harbor

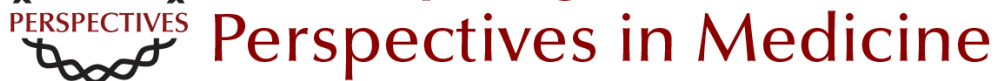

\section{Transcriptional Regulation in Prostate Cancer}

David P. Labbé and Myles Brown

Cold Spring Harb Perspect Med 2018; doi: 10.1101/cshperspect.a030437 originally published online March 12, 2018

\section{Subject Collection Prostate Cancer}

Anatomic and Molecular Imaging in Prostate Cancer

Eric T. Miller, Amirali Salmasi and Robert E. Reiter

The Epidemiology of Prostate Cancer Claire H. Pernar, Ericka M. Ebot, Kathryn M. Wilson, et al.

Prostate Stem Cells and Cancer Stem Cells Jia J. Li and Michael M. Shen

Prostate Cancer Epigenetics: From Basic Mechanisms to Clinical Implications Srinivasan Yegnasubramanian, Angelo M. De Marzo and William G. Nelson

\section{The Genomics of Prostate Cancer: A Historic} Perspective Mark A. Rubin and Francesca Demichelis

Neuroendocrine Differentiation in Prostate

Cancer: Emerging Biology, Models, and Therapies Loredana Puca, Panagiotis J. Vlachostergios and Himisha Beltran

DNA Damage Response in Prostate Cancer Matthew J. Schiewer and Karen E. Knudsen

Transcriptional Regulation in Prostate Cancer David P. Labbé and Myles Brown
New Opportunities for Targeting the Androgen Receptor in Prostate Cancer Margaret M. Centenera, Luke A. Selth, Esmaeil Ebrahimie, et al.

Prostate Cancer Research at the Crossroads Michael M. Shen and Mark A. Rubin

Immunotherapy for Prostate Cancer Nicholas J. Venturini and Charles G. Drake

Molecular Pathology of High-Grade Prostatic Intraepithelial Neoplasia: Challenges and Opportunities Levent Trabzonlu, Ibrahim Kulac, Qizhi Zheng, et al.

Metastases in Prostate Cancer Federico La Manna, Sofia Karkampouna, Eugenio Zoni, et al.

Genetically Engineered Mouse Models of Prostate Cancer in the Postgenomic Era Juan M. Arriaga and Cory Abate-Shen

Molecular Biomarkers in the Clinical Management of Prostate Cancer Aaron M. Udager and Scott A. Tomlins

Metabolic Vulnerabilities of Prostate Cancer: Diagnostic and Therapeutic Opportunities Giorgia Zadra and Massimo Loda

For additional articles in this collection, see http://perspectivesinmedicine.cshlp.org/cgi/collection/ 